\title{
Huns on the Ruins of Socialism: Public Past in Inner Asian Cities
}

\section{Abstract}

This paper examines the process of Hunnic symbols introduction to urban space. The question is, why rapidly expanding and modernizing cities at the same time create so many references to ancient archaeological cultures that previously played almost no role in the urban or national culture? The main emphasis is on public past in two cities: Ulaanbaatar and Ulan-Ude. In order to provide insight into this variety of social behaviours, an increased focus is put on: indigenous placemaking, shamanic activity in the city, new temporalization and local politics of memory. As a consequence of these processes, new senses of urban space, time and history are established. The study presents the results of ethnographic fieldwork in Mongolia and Eastern Siberia 2018-2020.

Keywords: Inner Asia, Ulaanbaatar, Ulan-Ude, Mongolia, Siberia, Huns, placemaking, public past, urban shamanism, urban anthropology, post-socialism

\section{When history becomes a social fact}

The economic and social ideologies reconfiguration of the imagined past; not only its de-Sovietization but also nationalization or indigenization. It is challenging country, and Ulan-Ude is a city where the majority has always been Russian. However, recently we can observe an increasing number of urban Buryats as a result of immigration from rural areas. At the same time, Ulan-Ude is the capital of ethnic autonomy established by the Bolsheviks in early 1920. The Russians' demographic and historical domination in the Buryat Republic's capital is the cause of the ambivalence amongst Buryat newcomers. As shown below, this status mediation takes place through a series of performative acts of the public past. 
This article examines the process of Hunnic symbols introduction to the urban space because this issue has recently grown in importance not only in Buryat and Mongolian capitals but also in Inner and Central Asia, Turkey, and Hungary (Gökay, Aybak 2016: 109; Kürti 2015: 248; Kürti 2016). The question is, why rapidly expanding and modernizing cities simultaneously create so many references to ancient archaeological cultures that previously played almost no role in the urban or national culture? Why are Huns Avenues and Hunnic ringfort reconstruction created together with skyscrapers, shopping malls, and apartment buildings? In the case of Ulaanbaatar, its public past harmonizes with the state's historical policy. On the one hand, one might risk putting forward the thesis that by means of national ideology, an attempt is made to re-bond a society constantly defragmented by resources-oriented capitalism deepening social and economic disparity. There is a need for more and more new figures and historical frames unifying society beyond class divisions in this process. History is now arranged to demonstrate the Mongolian nation's eternal presence over time (Kaplonski 2004: 175). Caroline Humphrey writes about the phenomena of "embodiment" and "historical mimicry". Embodiment involves the identification of contemporary people with those from the past. Historical mimicry refers to the reproduction of events or physical objects that have the symbolic capacity to represent the ideas, regains historical and cultural continuity of moral authority, and provides moral authority in pastoriented post-socialist Mongolia (Humphrey 1992: 376-380). It means that the past provides an interpretive framework for present events.

Analysing post-soviet Buryatia, Justine Quijada Mikhail Bakhtin's chronotope, which links the place with the past. For Quijada, chronotopes are rooted in the culture, forms of the perception, categorization, and articulation of time and space. In Ulan-Ude, chronotope provides sustainable spatial and temporal frames that define individuals and groups' status and rights in urban space (Quijada 2019: 11). "Landscape is full of named locations where time and space have fused and where, through the agency of historical tales, their intersection is made visible for human contemplation" (Basso 1996: 62).

From a certain point of view, Ulaanbaatar serves as a role model for Ulan-Ude, which adopts the ideas and forms of development and ethnicization of a post-Soviet city. However, adapted practices work in a different social context where ethnic diversity and the traditional domination of Russian culture in urban space are crucial issues. In the case of Ulan-Ude, hitherto subordinate groups, e.g. indigenous immigrants in the city, use the public past tools to mediate their status in urban space. On the other hand, within the new capitalist order, commercial brands and the tourism industry appropriates local history and historical images selling cultural diversity to visitors and appealing to local customers' national sentiments (cf. Bulag 2002: 221).

Furthermore, the public past's role in post-Soviet cities' transformation should also be considered in the broader context of national historical policy. Nationalist 
mobilization is possible due to creating common images of the past and origins (Coakley 2004). Forming national politics of history has begun responding to the demand for new social identity axes and new institutional building instruments. Politicians continuously appeal to the past because it is the principle that organizes the imagination of the social order and social identities in the modern state. In Russia, most of Yeltsin's and then Putin's attempts to replace the Soviet metanarrative by new national mythology and identity markedly fell flat. The Soviet past is too important to be ignored or rejected, but it is challenging to integrate it comprehensively due to its totalitarian nature. Therefore, attempts are made to use the positive elements of the Soviet past selectively ${ }^{1}$ (Gill 2013: 222-244). A similar ambivalent status to the socialist past keeps on in Mongolia, where, on the one hand, it was a period of gaining state subjectivity, liberation from Chinese domination, and rapid modernization. However, on the other hand, these processes were accompanied by repression and subordinated role of the USSR's satellite state (Kaplonski 1999; Pedersen 2006).

At the same time, the political elites of ethnic minorities began to revise the existing historical narratives, trying to create their national historiography that would allow, first of all, to overcome the stereotype of "cold" "people without history", which were included in the historical process thanks to Russian or Chinese colonization. New ethnic historiography, written by both local professional historians, dilettantes, and representatives of other scientific disciplines, relegitimised the ethnic autonomies created in Soviet times and helped negotiate relations with the state and ethnic majority. Neil Whitehead writes about "indigenous historicities", emphasizing their particular understanding of time, knowledge, and being that make the past meaningful (Whitehead 2003: xi). ${ }^{2}$ In Inner Asia, alternative regimes of historicity are used by post-Soviet ethnic minorities to process their political and cultural emancipation. Marshall Sahlins wrote about mythopraxis, which he defined as the organization of historical action as the projection of mythical relations; the practical way people find themselves in history (Sahlins 1983: 526-531). In this paper, we consider mythopraxis a leading mechanism

In the public sphere, this process was most visible in the urban space, where Soviet industrial cities were gradually transforming into ethnic, often pre-colonial capitals. These socioeconomic changes went along with intensive transformations

\footnotetext{
Russian authorities are trying to control historical policy in Russia by means of legal regulations. In 2014, criminal liability for "falsifying history" was introduced and in 2020 the head of the Russian Investigation Committee (a structure modelled on the FBI) established a special unit for crimes against history. The protection of historical memory was included in Amendment No. 3 which the Russian Constitution adopted in 2020: "The Russian Federation honours the memory of the defenders of the Fatherland and protects the historical truth. Diminishing the significance of the people's feat in defending the Fatherland is not allowed". Probably the main intention of the legislator was to protect the state's interpretation of the role of the USSR in World War II - a victory in which it is promoted as the keystone of Russian national identity.

2 Cf. Hayden White's concepts of "historical" and "practical past" (2012).
} 
in cultural and political identity that manifest in efforts to imbue urban spaces with new frames of history and nationalism (Diener, Hagen 2013: 642). Practices of a reorganization of the memorative landscape should be considered as authorities and local groups' attempts to overcome their post-dependence status and reintegrate the Soviet experience materialized and symbolized in the urban space. With the progressive urbanization of the post-nomadic population in the region, the cities became the main "assemblage points"3 of new social communities. A visible trend is to supplement the seemingly universal (indeed Soviet/Russian) urban space with local, national symbolism.

\section{Scourge of God in the Soviet panel block}

I arrived in Ulaanbaatar on a summer evening in 2019. The road from Ulan-Ude lasted over fifteen hours because, due to road works, our bus was forced to ride on the steppe, which often caused a flat tire. I took a taxi from the "Dragon" bus station that drove me to a cheap motel in the yurt district. I was ravenous, so I dropped off my backpack and went down the hills covered with yurts, modest bungalows, wooden fences, and old tires to protect the area from landslides in search of a cookshop. Pretty soon, I got to Hasbaatar street. Everything was closed, but I saw people heading to the grocery store. Hoping that they would let me in, I approached the entrance.

The shopkeeper shouted through the closed door that she would not let anyone else in. I was about to leave when two men offered to show me another store. I looked at them suspiciously. One of them, burly, dressed in black military clothing, wore a large silver swastika on his chest; the smaller one resembled heavy metal alky. I found myself in an embarrassing situation; it would be a faux pas to refuse help, and at the same time, it was dangerous to wander with strangers among garages and unlit houses. I thought to myself: "you came here to talk to people, so go and talk to them", so I agreed. We have wasted a good half hour wandering in the, and I lost my way very quickly. In the meantime, my new fellows asked me about the purpose of my visit to Mongolia. Finally, we found a working shop, and my companions bought a couple of bottles of vodka. They said: "if you are an anthropologist and are interested in our culture, you must come with us. We will introduce you to famous musicians, and we will take you to the apartment of one of the oldest metal guitarists in the city". So I went with them.

We took the elevator to the $9^{\text {th }}$ floor of a ragged Soviet-era tower block. A longhaired, lean-bodied, middle-aged dude opened for us - it was the house-holder.

3 Following Kim Dovey, it can be stated that urban assemblage is basically territorial. The concept of assemblage allows us to capture relations between spaces and places, ethnic and social policy and everyday practices. Assemblage theory analyses all places not as fixed and stable but as states of continuous change (Dovey 2015: 13-32). 
I took off my shoes and was seated on the carpet among a group of drunk bald men, interchanged with equally drunk longhaired men. My companions introduced me as a scholar and admirer of Mongolian history. "Chingis" vodka was poured into mugs, so we drank "To our meeting!"

Our host started showing me books on the history of Mongolia. Some books were known to me; others I was curiously leafing through for the first time. He asked me about various authors. Along with some names, he was puckering his face into a frown. He said:

You have to be careful whom you read. Some of the so-called Mongolian scholars are halfbreeds - mongrelized with Chinese and Russians. You cannot trust them. It is not known whom Baabar ${ }^{4}$ works for - Chinese, I think. Only pure-blooded Mongols can write the truth about our ancient history. Surely you know that we have conquered all of Asia and Europe?

Of course I now, The great Chingis khan and his generals: Batu, Subedei... - I tried to demonstrate my erudition, and some people nodded in approval.

Not only them - my interlocutor interrupted me - I'm talking about the Huns, our ancestors, who brought Europe to its knees. Have you ever read about Attila?

Was he also a Mongolian? - I asked with disbelief, tinged tone.

- The Scourge of God Atilla was the truest Mongolian ${ }^{5}$ - he said in a high voice.

- Pure-blooded Mongol $^{6}$ - added the bald man from my left.

- I raise my glass to Mongolian hero Attila - I said, so we drank.

We went to smoke on the balcony, and we talked about Mongolian alternative music. I stared at the hills covered with yurts and little bungalows of Attila's descendants. Then we opened another bottle of silver "Chingis" and sat back down on the carpet.

So how can you be sure Attila was a Mongolian? After all, the Huns, moving westward, incorporated several local ethnic groups into their ranks and mixed with them - I asked.

He was brave and fought like a Mongol - he was a real Mongol - you can read about it in these books; the Huns are Mongols.

And what about 'Lobruk'? Was he also a Mongolian? - the frail drummer, who had been napping on the bed, said suddenly.

Do you mean William of Rubruck - the monk who travelled and described the Mongolian Empire in the $13^{\text {th }}$ century?

No, I mean Ragnar Lothbrok, the one from the TV series Vikings.

It's rather unlikely - I replied diplomatically.

Why not? After all, Attila conquered all of Europe and must have fathered many sons. It is quite possible that Ragnar was his grandson. He fights like a Mongol - we are all watching this series here.

To Ragnar Lothbrok, possibly Attila's grandson! - exclaimed the bald guy on the left, so we drank.

4 Baabar - pseudonym of Bat-Erdenijn Batbajar - popular politician and history writer, author of History of Mongolia (1999).

5 Mong. Tengerijn Tašuur Atilla žinhene Mongol bajsan.

6 Mong. Cever custaj Mongol. 
Ragnar was an excellent Nazi, which is why he was probably a Hun too - muttered the lad in hat and silver swastika on his chest.

We are Nazis, and you are a Nazi too - the longhaired guitarist replied with the look of a Taoist sage.

I've never thought of myself like that - I replied, confused.

Don't you love your country?

Yes, I like my country.

So, you are a Nazi, like us!

A few toasts later, still hungry but already drunk, I was laboriously climbing the hill towards the yurt district, trying to guess where in this darkness my motel is lurking. It should be somewhere behind the brick public shower stall. In a state of temulent excitation, I thought of all those Hun descendants sleeping in the yurts and bungalows around me. Suddenly the headlights of an oncoming car blinded me. I instinctively took a step to the side, felt a void under my foot, and almost fell down the slope into the abyss.

\section{The spectre of Attila is haunting the city}

A strange adventure with members of the neo-Nazi subculture opened my eyes to the presence of the Hunnic symbols in the urban space, which I had ignored so far. During my first stay in Ulaanbaatar in 2005-2006, I witnessed a symbolic transition from the socialist to the national and capitalist order. Along with new architecture and chronotopes, a brand new temporal framework started reordering political and social categories. The mummy of Choibalsan, the Stalinist leader of the country and organizer of the great terror, was taken from the main Sükhbaatar Square and buried in a cemetery on the city's outskirts. His mausoleum, stylized as the mausoleum of Lenin, was demolished. Instead, a monumental structure was erected in this place, creating a new parade wing of the Government Building. In the centre of the structure, a monument of Chingis khan sitting on the throne was placed that completely changed the concept of state, power, past, nation, and place identity. On both sides of the throne, horse statues of his lieutenants were erected. His successors sitting on the thrones, son Ögedei and grandson Khubilai, were anchored in the building. Soon also the square itself was renamed Chingis Square. ${ }^{7}$ New skyscrapers have sprung up around the square, housing, exclusive hotels, boutiques, and companies' headquarters related to the mining industry. The tower stylized a bit like Tibetan monastic architecture, became the seat of the stock exchange. In summer 2006, the 800th anniversary of the Mongol State

7 The name change hit the Mongolian People's Party, whose co-founder was Sükhbaatar, and therefore the original name of the square was restored in 2016 thanks to the efforts of party activists. 
was celebrated. ${ }^{8}$ The origins of the state began to be counted from the proclamation of Temujin as the great khan (Chingis Khan) of all Mongols. Thus, statehood and the Mongolian nation were introduced into a different timeframe. So far, the emphasis of the anniversary cycle and official historical discourse were placed on the victory of the revolution in 1921 and the Mongolian People's Republic's proclamation in $1924 .{ }^{9}$

Imperial history changed the socialist revolution-based national history, but it did not involve a complete negation of the socialist period, as was in Poland and other post-socialist EU members states. Instead, the Socialist past was transposed into the new framework as part of the long-term struggle for restitution of independence and the Mongol Empire's former glory. Images of Chingis Khan and his descendants have become a commodity and tourist brands. I found images of khans on pub signs (e.g. Grand Khan Irish Pub, Chinggis Pub), on vodka bottles (Chinggis Gold, Chinggis Platinum, Khubilai Khan vodka), and hotels (Chingis Khaan Hotel) and even on matchboxes. Even the main airport was renamed Chingis Khan Airport, and in 2019, the Mongolian Cabinet decided to establish on the site of the natural history museum a museum for Chingis Khan. At the same time, statues of communist leaders began to disappear from central places in the city. In 2012, the bronze Lenin in front of Ulaanbaatar Hotel, ${ }^{10}$ a usual hangout for prostitutes, was removed. In its place, a monument to the writer Natsagdorj was brought from the Children's Park. However, the "young Lenin" standing in front of the Children's Palace and Choibalsan in front of the Mongolian State University's main building remained undisturbed in situ. The former patron of the main square, the revolutionary Damdin Sükhbaatar, persisted in Chingis Khan Square. He is parading on horseback in front of a higher situated khan.

8 Apart from the national Naadam festival and numerous concerts, the program of the celebrations included a public lecture by Professor Leszek Balcerowicz - Polish Minister of Finance who led the free-market economic reforms in Poland, which became a model for the Mongolian transformation. His lecture at the headquarter of the National Bank of Mongolia was attended by numerous and admiring audience, and the entire city centre was covered with posters of Balcerowicz.

9 Both events were initiated by the Mongolian communists with the support of the USSR and the Comintern. At the same time, the role of the proclamation of independence and the enthronement of Bogdo-gegen was marginalized in historiography and rituals of commemoration of the socialist period. At the same time, the figure of Chingis Khan and the statehood built by him were considered negatively as feudal formation, the shameful side of history based on despotism and dedicated solely to protecting feudal interests (Kaplonski 2005: 160-161).

${ }_{10}$ Few years before, the Stalin statue in front of the National Library was replaced with one of Byambyn Rinchen - a Mongolian writer and linguist (Diener, Hagen 2013: 634). 
Mongolian People's Republic and the Mongol Empire ${ }^{11}$ form two basic frames of Mongolian historicity inscribed in urban space, ${ }^{12}$ but in recent years, a third chronotope can also be seen - the Hunnic Empire. Academician Shagdaryn Bira intended to replace Marxist historiography by formulating a much broader temporal framework of the Mongolian nation and state institutions. In his interpretation of history, of institutions of power and state, from ancient India, through Tibet up to $13^{\text {th }}$ century Mongolia. ${ }^{13}$ The emphasis was also stressed on the states' cultural, institutional, and ethnic historical continuity in the Great Steppe from the Xiongnu (mong. Hunnu, $3^{\text {rd }}$ century BC $-1^{\text {st }}$ century AD) to the Mongol Empire $\left(13^{\text {th }}\right.$ century). It is in the Huns that Bira sees the prototypes of the institution of the khanate and the cult of the main deity - the Eternal Blue Sky - as a religious sanction on the supreme and undividable power of the khan (Bira 2000, 2004; cf. Dohnal 2015; Bulag 1998: 102). In subsequent, less critical, historical publications, Xiongnu, known from Chinese chronicles, were identified with the Huns, and these, in turn, were identified with the Mongols. The simple proof of both groups' sameness is evidenced by the fact that the ethnonym Hun means "man" in Mongolian. In the National Museum, archaeological finds attributed to the Huns are exhibited in the "Ancient Mongolian States" section. ${ }^{14}$ Thus, such archaeological culture was assigned to the historical, ethnic group (the Huns who invaded Europe), and this, in turn, has been identified with the modern Mongolian people.

This was evident in the statements of many of my interviewees who were not professional historians. My interlocutors in Ulaanbaatar were proud to inform me that the Huns managed to gain ground not only in China but in Europe too. Attila the Hun also subjugated the Roman Empire. The fact that the Mongols brought Europe to their knees twice (under the command of Attila and later on under Batu Khan) was a reason for national pride. In my opinion, my interlocutors were trying to show that they are not merely representatives of a small, underdeveloped country, which for decades was subordinated to the Soviets, but that the vital force of their passionate ancestors, Attila and Chingis Khan, smoulders inside them.

11 It is worth noting that Chingis Khan became a key historical figure of pre-socialist nationalism. The poet and historian Vanchinbalyn Injinash, author of The Blue Chronicle, in which he described the glorious past of the Mongols of Chingis Khan's time and Yuan dynasty, made a huge contribution to the resurrection of the figure of Chingis Khan at the turn of the $20^{\text {th }}$ century. An important role in the Pan-Mongolian national movement was played by Buryat scholars who referred to the sources and methods available in Western historiography.

12 Of course, one can observe the museum remains from the period immediately preceding the rise of the republic - the reign of Bogdo Khan: the summer palace, oracle temple and the partially preserved Gandan monastery.

13 Links between the Mongols and ancient nomadic statehoods were attempted in 1934 by Anandyn Amar in his book Short History of Mongolia - Mongolyn tovč tü̈̈h. Amar - head of the state and prime minister of Mongolia in 1930 - was repressed end executed in Moscow in 1941.

14 In fact, it is difficult to clearly define, not only the links between the Xiongnu and the Mongols, but even the links between the Asian Xiongnu and the European Huns. These links are the subject of long dispute in the scientific community (see: Atwood 2012). 
Taking into account the ongoing process of breaking away from socialist structures and the historical foreignness of capitalism, historical mimicry of ancient institutions and embodiment of figures from the past could be seen as attempts to domesticate a new socioeconomic order based on a free-market economy.

This retro-hallucinatory raising from the knees took place in anticipation of the upcoming national glory since, in this historical framework, to conquer the world over and over again seems to be the destiny of the Mongols. Such mythopraxis, which introduces Hunnic myth to social practice, help rebuild national identity during the post-socialist transition and. The Huns and their country are sometimes referred to as a benchmark in political debates. During a fierce dispute over land privatization in parliament, Sarlagtay Mashbat ${ }^{15}$ spoke out against privatization, referring to the state traditions of the Huns. In the manifesto published later, he wrote:

The Hunnu Empire, the nomadic people's first empire in what is now Mongolia, was founded in 209 BC. The current heritage of Mongolian statehood has profound roots in the Hunnu Empire. The very first border agreement between Mongolians and Chinese was made by the Shanyui (king or emperor) of the Hunnu Empire and the emperor of the Han dynasty in 198 BC. The Spring and Autumn sessions of the State Great Hural (Mongolia's parliament) have their origin in the Hunnu Dynasty. One of the principles of nomadic statehood, perhaps the most important one, was stated by Modun Shanyui, the first Shanyui of the Hunnu dynasty. He said: "The land is the ground of the state". Later, this quote was interpreted as a restriction of land ownership, and the precept was strictly followed by successors of the nomadic statehood heritage.

The state enjoyed a monopoly on control of the land, and the land was the foundation of nomadic liberty. Nomadic liberty is fundamental. Mongolians, as a nomadic nation, do not like boundaries or limits. The mentality and lifestyle determined by animal husbandry cannot simply recognize any limits in any dimensions, including time and space. Liberty for Mongolians means "no limits". Many Mongolian folk tales and myths conflate time and space as they ignore the, to them, artificial boundaries imposed by these constructs. Unlimited nomadic activity means that there can be no private ownership of land. Land in a nomadic society is like the air or the ocean; it is impossible to divide and possess. It is not even public property, but simply a limitless expanse where we live and move. Nomads want to travel everywhere and across everything, without any limit. Can you imagine their thoughts if a stranger appeared before them, saying: "This piece of land is mine" and prohibiting them from going across it? To own a little piece of the landmass of the universe, saying: "It is mine", sounds to them like: "This cubic meter of air is mine, so, you cannot breathe it!". It is impossible to imagine. One reason for the Mongol Empire's greatness was the absence of any understanding of the "border" of land limits.

[...] Modun Shanyui's original testament is alive today (indeed, even the great Chingis Khan was not so brave as to break this testament), and all Mongolian dynasties have followed these words. There is no societal tradition of private land ownership, but today, with the move to an urbanized and settled society, the issue has to be rethought [...] There have been attempts to privatize land in the past. The Uigur and Kidan dynasties implemented a policy to privatize land under the influence of (Chinese) settled cultures. Unfortunately, these attempts were ended

15 Mashbat is a politician, a lawyer and researcher for the Institute for Strategic Studies in the Mongolian Ministry of Defense. 
by the collapse of their mighty dynasties. A third attempt was made during the Bogd Khan Kingdom of Mongolia (1911-1924), but the result was the same and was ended by the people's revolution in 1921. All three attempts were taken under the influence of powerful and imperialist neighbours, and the results were quite destructive. The current process is the fourth attempt at promoting land privatization. During the Communist regime, all land was state property (Mashbat 2004: 324-325).

In Mashbat's rhetoric, one can observe a characteristic pattern of cultural and institutional transmission from the Huns (Modun Shanyuni) through the Mongol Empire (Chingis Khan) and up to the $20^{\text {th }}$ century (Bogd Khan and the communists). The Huns become a reactive ancestor figure that points out the paths of Mongolian transformation.

The Huns became not only part of the official national discourse but also an essential element of the local pop culture and tourism industry. In Ulaanbaatar, Hunnu Street had recently been built east of Chinggis Avenue. On the river Tuul bank at Hunnu district road, the exclusive housing estate was called "Hunnu 2222 Residence", and on route to Chinggis Khan Airport, the massive Hunnu Shopping Mall was built. The building's facade was decorated with golden ornaments imitating the animal style characteristic of the Hunnic archaeological culture. Walking around town, I discovered that the Huns had become patrons of several restaurants, hotels, and travel agencies. As in Urdyn Bulag's case of Inner Mongolian Ordos, ethnic culture and history are being turned into capital within the ethnic tourism industry (Bulag 2002: 215).

Like Chingis Khan, the Huns seem to be starting to play the role of mighty ancestors who have the resources of life force and prosperity. There is a to communicate with the Huns and khans through shamans. Sometimes this kind of ritual is transformed into state ceremonies. In July 2006, President Nambaryn Enkhbayar took part in a shamanic offering (ovoo tahih) to spirits for the country's welfare on the $800^{\text {th }}$ anniversary of the Mongol Empire. The rites broadcast by television took place on a hill known for its ancient petroglyphs (also from the Hun period), located near the presidential residence and the great monument of the Mongol-Soviet brotherhood of arms. In this way, the state itself creates new chronotopes linking its institutions with the ancient past.

However, Hunnu penetrated not only official ceremonies, urban toponyms, and commercial brands. The Huns leaked into urban soundscape and fashion. I heard the music of folk metal band The Hu over and over from car speakers and bars. The band calls their style of music "Hunnu rock", and the Huns inspires the name "Hu". The Hu uses traditional Mongolian instrumentation, such as morin huur, tovšuur, and höömij - throat singing and became the first Mongolian band to gain worldwide fame. In recognition, in 2019, the band was awarded Chingis Khan's order by the president, and the band recorded a song praising Chingis Khan also with epithets traditionally attributed to Attila - the Scourge of God (mong. Tengerijn Tašuur). In this way, the Huns and the Mongol Empire were tied together with another knot of pop. Increasingly, the urban soundscape is 
disturbed by the roar of Harley-Davidson engines on which members of the most numerous Hunnu International Motorcycle Club ride.

Daily ties to the past are also formed from the bottom up as people create Hunnic fashion, furniture, rock music, tourist souvenirs, tattoos, karaoke clubs, and motorcycle clubs. However, it should be remembered that these manifestations of past-oriented "banal nationalism" (Billig 1995) are also often associated with animistic practices of obtaining happiness and life force from powerful spirits (see: Tangad 2016: 139).

Hunnic fashion has mastered not only fashion shows but has become part of everyday life. While I was interviewing a tailor in a small atelier, she began to encourage me to order a folk shirt. She presented the catalogue and asked which style I like best. After reflection, I pointed to one model with my finger.

- Perfect! - she shouted with delight. - Hunnic shirt is the most fashionable look this year. All elegant men are ordering Hunnic shirts.

- But why is this fashion called Hunnic one? - I asked.

- The Huns wore such shirts, the tailor replied without hesitation.

Shortly after that, while waiting my turn at the barbershop, I browsed through magazines and found out that the cashmere factory and the Gobi fashion house had already launched an entire collection of Hunnic fashion in 2016 to mark the occasion of the national Naadam festival. I was surprised to read that Naadam 2016 was dedicated to essential state anniversaries:

The $2225^{\text {th }}$ anniversary of the First Mongolian State - the Hunnu Empire, the 810th anniversary of the founding of the Great Mongolian State, and the 95th anniversary of the Mongolian People's Revolution. [Therefore] the Gobi company has released a new summer collection of deel that combines traditional and modern styles, colourful shawls with unusual national prints.

A week later, I was leaving Ulaanbaatar dressed in a bespoke, blue Hunnic shirt. At Chinggis Khaan International Airport, I boarded the Hunnu Airlines' plane Fokker 50 and flew to Ulan-Ude, a city entering a critical stage of Hunnic transition.

\section{Cossacks in dire straits}

In February 2012, at the City Hall of Ulan-Ude, public consultations were held. The assembled activists and officials should have selected the Cossacks' best design - the city founders' monument. The consultations were broadcast by the local broadcaster TV Arig Us, so residents had the opportunity to witness the dispute between Russian and Buryat social activists:

- Bakalin Vasiliev, Buryat, a labour hero: building a monument to the Cossack-aggressors on Buryat soil will be a humiliation and an insult to the Buryat nation! 
- Emma Kuznetsova, Russian, member of the Initiative Group for the monument to the Cossack Pioneers: The monument, in the end, is for those who built winter camp here for the first time, where our city has its origins.

- Piotr Roshchektaev, Russian: A monument should be erected to the city's founders who started its construction. Not to horses, not to sparrows, not to goats, not to anyone else, but the city's founders!

- Nikolai Fedotov, Buryat, president of the National Initiative Foundation: I propose to delve into history, look at Attila's ancestors, who...

- Roshchektaev interrupts: we have already delved, they are sitting here, the descendants of the Huns, we have already delved deep enough. How do you propose to name the monument? If not the founders, then...

- Don't build at all! - Fedotov comes in.

- Ivan Manuev, Buryat: People, on such important issues, in such difficult conditions, we cannot make decisions. Let's come to our senses, and let's postpone this issue for later consideration. Let our future comrades solve this problem. Now let's deal with housing, public transport, healthcare. ${ }^{16}$

During the consultations, no time was found to examine all twenty projects of the monument to the city's founders. The debate was dominated by the question of whether such a monument could be erected at all. The Russians, referring to the objective historical truth, tried to use the monument to anchor their relationship with the city. Buryat activists, opposing the monument's construction, suggested that the Cossack settlers' commemoration would be an apotheosis of colonialism degrading the native nations. Instead, they claimed that the city's real founders were the Huns - ancestors of the Buryats. Colonial, Cossack-oriented history has become doubly untrue to the Buryat side of disputes. Firstly, it was harmful to them because it commemorated the Buryats and Evenks' subaltern status and reminded them about the Russian roots of the city, preserving the traditional division into a Russian-speaking city and a Buryat village. Secondly, Buryat activists prefer to look for the origins of urbanization in the Huns' settlement, which archaeologists discovered in the suburbs.

The public consultation was only one episode in a 30-year conflict over the city's public past. In 1991, on Batareinaia Barrow, near the Uda River, in a place identified by archaeologists as the first Cossack fortification location, a group of Russian nationalists and Orthodox clergy erected a stone cross dedicated to the Cossack pioneers - the founders of the city. Over time, the modest cross was to be replaced with a larger more impressive monument. The construction however, sparked protests by Buryat activists. Not far from the Cossack cross, on the site where it was believed that the Cossacks could hold Buryat hostages (amanats), they erected wooden hitching poles (sergee), symbolizing the initially Buryat character of this territory. In this place, shamans began to perform tajlgan - public prayers with burnt sacrificial rituals for the master spirit of location (ezyn) and their ancestors (Nowicka, Wyszyński 1996: 135-136).

16 Internet resource: https://arigus.tv/news/item/18610/ (access: 23.11.2018). 
It was one of many shamanic practices of ethnic placemaking that transform the hitherto framework for the city's chronology. Along with this transformation, the symbolic appropriation of the urban landscape takes place. Shamanic practices undermine the colonial order and change the place's identity (cf. Dovey 2015: 3-12). Their subaltern status is ultimately overcome through the ritual expression of hostility to official narratives, and new temporality is established. Thanks to performative shamanic practices, the academic monopoly on the past and the hierarchies created within it are undermined. By ritual performance, shamans subvert Russian domination of the city and the right for its past. Unlike in Soviet times, the state is no longer the monopolistic guardian of the past. Public memory becomes a battlefield for two main ethnic groups with unequal and ambiguous status: the Russian urban majority and the Buryat - the Republic's titular nation but newcomers to the city. It is an apparent paradox that Russians generally do not take part in such rituals, but their social status is being transformed there. It is challenging to clearly say to what extent ethnic Russians are alienated during this urban space process. Some local Russians confided that "the Buryats went over the top" or "they are trying to do some Ulaanbaatar".

On the other hand, many of my Russian interlocutors were not without the approval of the new ethnic symbols in the urban landscape. These people emphasized that Ulan-Ude stands out from hundreds of other, generally identical, and uninteresting provincial Russian cities thanks to this. In their opinion, both Baikal and Buryat folklore attract tourists, which, in turn, has a positive effect on the economy. Nevertheless, at least some Buryats and Russians are involved in the dispute over symbolic domination in urban space, and the past is the fourth dimension of this conflict.

has developed a forcible counter-narrative to Russian colonial historiography. After this, local Buryats have started to claim that the Batareinaia Barrow was an ancient shamanic sacred place:

Before the Russians built the fort, there was a Buryat worship place in this place. On that site, our shamans had been offering worship to powerful [spirits] lords of this land. Russians intentionally built their stronghold on this place, as they built churches on our holy places. In effect, the Buryat community started to take a dim view of Russian activists' efforts to establish a monument to Cossack pioneers, and a strong grassroots lobby against building the monument appeared. Perhaps for Russians, the memorial was crucial to establishing and maintaining their identity. Through this monument and celebration of city location anniversaries, they try to organize and delimit citizens' individual memories. However, for Buryats, it was an unacceptable attempt to humiliate their dignity and take possession of the history of their capital. It is common to assemble public memory in the public space using historical monuments to stake a claim to the city (Bulutov 2012). 
The City Council and local government prefer to talk about the "peaceful incorporation" of Buryat tribes and land into the Russian Empire. ${ }^{17}$ For fear of interethnic hatred, commemorations of Russian colonial domination are unendorsed by local officials. On a more subtle level, forgetting Russian domination is a part of the silent decolonization of urban space and enables Buryat newcomers to obtain the city's hosts' identity. Resistance against the monument has encouraged people to criticize the Russo-centric character of urban history. Some journalists, scientists, and bloggers have started to cope with the native status of "people without history" by creating an alternative history of Ulan-Ude. During this process, no scientific procedures have been performed, so primary historical sources have been enriched with folktales, legends and become full of fads and fancies. Nevertheless, it has the performative power to conquer the city's past and sacralise/ethnicise some public sites.

The Uda estuary and Selenga banks were a pretty busy place. There was a place called "ChuckieStone" and on the top of that rock was an oboo. [...] Shamanicrituals attracted to the "Chuckie-Stone" large numbers of Buryat nomads. [...] Another significant factor is that the Uda estuary was a part of the nomad lands, the ulus [state] of Buryat-Mongol prince Turukhai Tabun - a wellknown historical figure. Here we can see that at the Uda estuary (in Buryat-Mongolian Udyn Adyg) - until the alien Cossacks came, there stood two sacred oboo. It means that this is a sacred place of the Buryat-Mongols. Furthermore, according to Federal Law No. 136-F3 of June 30, 2013, to counter the actions offending religious beliefs and feelings of citizens, two sacred oboo should be restored to the sacred place in the Uda estuary. Only these two sacred oboo have the right to stand at that place and nothing else. No need to commit sacrilege yet again! (Vasil'ev 2015).

The former Cossack fort has been a starting point for the process of new indigenous temporalization. Various practices: shamanic rituals, selection of historical evidence, and folk tales are consequently used to reframe the native public memory, and also other urban sites have become scenes of shamanic rituals of subversion. One of the most popular locations for shamanic rituals is a suburb called Verkhniaia Berezovka in Russian, whose Buryat name is Deede Ongostoi ("the upper place filled with ancestral spirits"). ${ }^{18}$ This terrain was incorporated within the limits of the city in 1930, causing several Buryat households to be displaced to another rural region. Although the master plan for this area was created in 1930, there was little subsequent development, and the land kept its peripheral character until the 1990s. The only remarkable investment was the huge open-air Ethnographic Museum. Nowadays, the district is mostly a leisure centre and a cottage area. After the USSR collapsed, Buddhists built a monastery there,

${ }_{17}$ V. Nagovitsyn - the head of the republic, on the occasion of the anniversary, published an article in a scientific journal entitled 350 years of voluntary entry of Buryatia into the Russian state (2011).

${ }_{18}$ In fact, the word ongostoi means "pine forest" (Badmaeva 2005: 76), but probably as a result of shamans' activity people started to associate this word with ongontoi - "a spirit". 
and the Orthodox Church erected a modest shrine. Local Buryats claim that Deede Ongostoi is a mighty place, and these were local spirits that did not allow the Soviet authorities to build any industrial construction there. The spirits only permitted the museum in a bid to additionally empower this land with a large number of shamanist exhibits (Hürelbaatar 2007: 145-147). In the opinion of native activists, Deede Ongostoi became a shamanistic sacred place after the Cossacks settled down on Batareinaia Barrow and cut off the road to the previous sacred spot (Bulutov 2012).

The construction of the Cossack monument is still subject to obstruction. Soon after, the polemic about memorial had moved to the Internet, turned into a regular exchange of invectives between Russian supporters and Buryat opponents of the monument's construction. As a result, one Buryat blogger was tried and convicted of inciting ethnic extremism. ${ }^{19}$ The conflict over control over the city's history is part of the struggle for the right to the city. We are dealing with a case of binding the memory with public space. So-called public memory should be considered a framework of history enshrined in historic sites and public monuments that work alongside tradition to guide that idealized memory and present established social order as natural (Gordon 2001: XV). Buryat ethnic activists do not stop at negative resistance to the Russian monumental propaganda. The city's new timeframe has recently gained its architectural representations reflected on so-called Hunnu City. With the help of competing mythopraxises (Hunnic and Cossack), the city, its space, identity, and power relations are being reconfigured.

\section{Hunnu City}

The Ivolga archaeological site, located nine miles from the city centre, for the first time, was excavated in the 1920s. However, it did not play a central role in the city's historical politics until the 2000s. The new interest in the ancient settlement appeared not only for the next stage of archaeological research. It was not either a direct result of cultural or heritage tourism. Remains of structures from the $3^{\text {rd }}$ century $\mathrm{BC}$, barely visible in the steppe landscape, became the subject of the Neo-Hun organization's increased interest. The International Hunnic Foundation began to propagate the scientific hypothesis that Buryats were descended from the Xiongnu as a matter of course. Nowadays, it is a common idea that the Xiongnu (interchangeably called Huns or Hunnu), who built the settlement, are close-related ancestors to present-day Buryats.

Since 2005, the International Hunnic Foundation has been organizing the Hunnic Culture Festival on the settlement territory. Also, Buryat shamans have started to perform rituals within the archaeological site called the Hunnu City

19 Interview with Aleksey Mikhalev, Ulan-Ude, 2.07.2018. 
(bur. Hünnü hoto). In 2011, The Buryat State Academic Opera and Ballet Theatre staged Attila by Giuseppe Verdi there, after which a Hunnic fashion week was held. Moreover, the Hunnic Fond and local archaeologists are striving for UNESCO World Heritage status for the Hunnic archaeological site. This "historical mimicry" was also accompanied by scientific conferences and museum exhibitions devoted to the Huns. The city authorities established the Day of the Ancient City of Huns on September $5^{\text {th }}$ (Dašibalova 2017).

The new periodization of urban history was presented in a film by the president of the Hunnic Foundation, Oleg Bulutov:

We are not only descendants of the Huns, but we are Huns, and we have to understand this about ourselves. Moreover, the history of Hunnu City is our history. [...] 2,300 years ago, the city was already here, and the first burgers appeared in that period; there were a school there, crafts workshops, houses. [...] The whole territory around had been inhabited. On the place wherein the $17^{\text {th }}$ century Cossacks built a hillfort, we had had a trading factory for Middle Asian merchants. [...] It was a medieval factory, from the $9^{\text {th }}$ century to the $15^{\text {th }}$ century. [...] Cossacks were the latest wave of immigration to the well-dwelled area, and they considered themselves as descendants from the Huns, too, since they used to belong to the Golden Horde.

Thanks to the efforts of the foundation and with the support of the republican Ministry of Culture and Russian Geographical Society, in 2019, a wooden reconstruction of the settlement was built, with houses, defensive walls, and a gate, in which Oleg Bulutov, dressed in Hunnic armour, solemnly greeted the head of the Republic of Buryatia, Alexey Tsydenov. Within the fortifications, there is an archaeological park with yurts and houses, in which Buryats dressed as Huns tell tourists about their ancestors, host Hunnic cuisine, teach how to shoot a bow, and ride horses. As in other ethnic investments in urban space, concern for "cultural heritage" goes hand in hand with the cultural tourism development program. An arena and Hunnic craft workshops, military barracks, and a souvenir shop will be built there in the future. There are also plans to organize some republican celebrations and ethnic festivals in the Hunnu City territory. In an interview with Channel 1 of Russian Television, Bulutov stated: "It is our history, our ancient capital, the most sacred city. It is at least 2300 years old, so this is the most ancient city in Russia. We are now restoring it to receive all [Hun's] descendants". ${ }^{20}$ In an interview with the local TV station ATV, Bulutov developed his urban concept:

Where are we? - the journalist asked.

Here is our ancient place. We are located in our capital, Hunnu Capital. We are located on the outskirts of the city and are now reconstructing this peripheral residential quarter. We are only beginning to reconstruct one part of the city.

- So this is the capital of the Huns?

- Yes, it is the Capital of the Huns, the largest and most explored city of the Huns.

It is actually Ulan-Ude. We drove here from the centre in 10 minutes.

Ulan-Ude is such a new neighbourhood unit of the old city. [...]

20 Internet resource: https://bgtrk.ru/news/society/182898/ (access: 24.09.2020). 
Why the Huns? Why not Cossacks, not Mongols, not Buryats? Why not some Buryat clan? - the journalist asked.

In Buryat, we call ourselves Hünüüd - it means "people", hün means "man". We consider ourselves Huns; I am from the Bulagat tribe. The Huns were divided into 24 tribes. We Bulagats are one of the surviving tribes of the Huns. The Sky above us has apparently ordered to do it.

Are the Buryats Huns?

The Buryats are descended from the Huns and are themselves Huns. Why? Because children donate their blood to their children and geneticists, they have already proven that the Buryats are closely related to the Huns.

Later in the interview, Bulutov explains that the Huns drank toadstool decoction before the battle and used shields like shamanic drums, so they fell into a fearless trance. He also talks about his cooperation with Hungary and Kazakhstan and developing the Bulagats tribal organization.

In today's world, it is not necessary - the journalist objected - if I start explaining my origin, from which Slavic tribe my ancestors come from, I will waste much time on entirely useless activities.

Why? Because we are in the process of returning to the past - especially the Buryats. We are starting to look for our roots. Why? Many people go into retreat, become oracles, shamans. They go back to the old faith, to paganism because their ancestors demand attention from them; they say: why don't you remember us, why don't you know your ancestors up to the $12^{\text {th }}$ generation? Moreover, regardless of their tribal affiliation or faith, many Buryats have started to study their genealogy because, within their tribe, they have to perform offering rituals for their ancestors to prosper and that children are healthy and ancestors are happy. Thanks to this, the forgotten culture and tradition in those [Soviet] times are now being renewed. ${ }^{21}$

Symbolically appropriated by Buryat activists, archaeological sites were included in the order of the ethnic tourism industry (cf. Comaroff, Comaroff 2009) and became an element of the ethnic reframing of the urban past. Along with identifying Buryats and ancient Huns, classical urban temporality is contested. The Huns play the role of the first urbanites and builders of the city 2,300 years ago, a long time before Russians appeared. Russian colonization and the Soviet period are transformed into relatively insignificant episodes in the history of the ancient city of the Huns. The idea of Ulan-Ude as the oldest city in Russia is propagated not only by the Hunnic Foundation but also by the City Council, probably because it is counting on tourism growth. The archaeological site becomes a centre for the indigenization of the urban past.

Turning archaeological sites into ethnic places is the modern practice of new historicity that undermines Russian hegemony in the urban past and present. This site links urban Buryats with the pre-colonial period. For that reason, shamans perform rituals in Huns City, where evidence of Hunnic/Buryat past activity is preserved. In this case, mythopraxis obtains its spatial and ritual manifestations. Michael Guggenheim argues that "modernity is a process that tends to turn any-

${ }^{21}$ Internet resource: https://www.youtube.com/watch?v=siTDAe0SYgI (access: 25.09.2020). 
thing into an object with a history and a biography" (Guggenheim 2009: 39). Thus, temporalization is accompanied by a boom in the protection and restoration of memory sites. It also provokes conflicts about the destiny of monuments, buildings, and archaeological sites. From that perspective, it is a process of the new temporalization of Ulan-Ude and its transformation to Hunnu City. Shamanic and Hunnic chronotopes are part of a new development strategy that turns postindustrial Ulan-Ude into a city of cultural tourism. ${ }^{22}$ Buryat ethnonationalism is strongly market-oriented and has become a significant part of the urban landscape. ${ }^{23}$ When I discussed the Cossack Monument with Prof. Alexey Mikhalev, he told me:

I suggested creating a society of the descendants of the first settlers of Vierkhneudinsk, allocating land for them in the city centre, and erecting there a monument to Gavril Lovcov and Osip Vasilev - the founders of the city. That it would be built as a private monument that was erected by descendants to their ancestors; in this way, the memory would not belong to the city or its inhabitants, but a particular NGO. Unfortunately, no one supported this initiative - everyone is afraid.

So in the fight for the symbolic space and the past, the Huns win over the Cossacks so far? I asked.

Well yes - answered Mikhalev - because Huns are real and Cossacks do not exist. Cossacks are mostly carpetbaggers and mummers. ${ }^{24}$

The Huns exist as a social fact because they have an active Buryat group that claims to be their descendant and inheritor. Contrary to this, Cossack movements researcher - Ivan Peshkov claims that local Cossacks probably do not want to involve in interethnic contention. ${ }^{25}$ On the other hand, the International Hunnic Foundation managed to convince the Buryat Republic authorities and the city that their vision of the past is ennobling for the city (Ulan-Ude becomes the oldest city in Russia) and fits perfectly into its development plans (centre of cultural tourism).

The very location of the reconstruction of the archaeological site is also significant. The city of Huns is not far from Ivolga Datsan - the main Buddhist monastery in Buryatia and the seat of its head, the Khambo-lama Damba Ayusheev an influential religious and ethnic leader, promoter of the anti-urban project of returning to the pastoral lifestyle. It is also an urban sprawl area, where a subur-

22 An important role is played by the ethnic culture festivals organized in these places, aimed at both tourists and local people (see: Nowicka 2015). This way of unhistorical ethno-representation imposes forms of self-representation of the Russian majority, which manifests itself as Cossacks or as Old Believers.

23 The given examples are only a fraction of the complementary or competing post-socialist urban frames in Ulan-Ude. Anatoli Breslavsky lists the ideas of: "cities with an Asian soul", "Buddhist capital of Russia", "Russia's Eastern Gateway", "the capital of Buryat world" and "a city on the Great Tea Road with strong merchant traditions" (Breslavsky 2012).

24 Online interview with Alexey Mikhalev, Poznań-Ulan-Ude, 21.09.2020.

25 Online interview, Poznań-Moscow, 28.09.2020. 
ban zone of several dozen miles long wooden buildings is being created, combining elements of rural and urban modes of life. The suburbia, inhabited mostly by Buryats, begin to form new patterns of urbanization. For some, it is perceived as the city's ruralisation; for others, it is a space of compromise between traditional, post-nomadic culture and modern urban culture. With the construction of the city of Huns, the type of suburban urbanization gained another institution mediating its place in Ulan-Ude's urban fabric. ${ }^{26}$

\section{Conclusion}

The broad implication of present research is that Huns are becoming an increasingly important element of the public past, serving as the basis for numerous commemorative markers in Inner Asia's urban space (Shnirelman, Panarin 2001: 14). The question must be answered here: How exactly has the Hunnic factor affected public past patterns over the past 30 years? Following Benedict Anderson, it can be assumed that antiquity is, at a certain juncture, the necessary consequence of novelty (Anderson 1991: xiv). This statement is particularly relevant for several post-socialist national groups whose state institutions had been established by the Bolsheviks. Until 1991, they were dependent on the USSR's central authorities and submitted to soviet cultural hegemony, also in the field of history. In Buryatia, where the republic is only a weak substitute for statehood, representatives of the "titular group" try to confirm their right to the city by proving its autochthonic origins. The establishment of ethnic chronotypes and reframing the city's history is part of the symbolic struggle of urban space. This struggle results from the mass migration of Buryats to Ulan-Ude and the collapse of the Soviet paradigm of organizing urban space, social relations, and ethnic representations.

Linking the Buryats with the Huns and the Huns with the origins of the city gives Buryats the status of hosts and city founders. In this way, the discourse on Buryats' allochthonous character, which is common in the neighbouring academic centres (e.g. in Irkutsk), is undermined. The spread of the belief that the Buryats and Russians arrived in the Baikal territories simultaneously challenges Buryat exclusive rights for the territory and the sense of republican autonomy.

In Mongolia, referring to Chingis Khan and the Huns' legacy allows the retroactive creation of cultural and state continuity. Thus the recent status of a satellite state

26 In the spring of 2010, I was invited to one of the first meetings of this women's organization. At that time, the group consisted of wealthy Buryat women who had achieved professional success, but also fulfilled themselves in their family life. The ladies claimed the right to represent the female voice in the public sphere, implement projects to revitalize Buryat culture in the city space, and promote family values. Elena Bandueva, one of the leeders, explained to me that "by choosing Oelun as the patron of the organization, we want to realize this power and wisdom, motherly compassion that was realized by mother of Chingis Khan". 
of the USSR is overcome, a status ambivalently assessed as socialist Mongolia has acquired state subjectivity. The process of nation-building and modernization has started. At the same time, The Mongolian People's Republic was not a fully independent country. The "Empire of the Huns" and the "Mongol Empire" provide an interpretive framework in which the ancient Mongolian nation experiences the pulsating process of the decline of statehood and its re-blossoming into incredible power. History becomes not only a source of pride but also its promise.

In both cases, the ties with the past are even more robust as they are not only created from the top-down by the state through education, cinematography, historical politics. The past is also experienced through the worship of ancestors who provide prosperity and vitality to descendants. It has been shown how various practices and elements of architecture affect the urban space transforming the local notion of history, nationality, and interethnic relations. We are dealing with a new assemblage of soviet and modern architecture with national/ethnic, past representations, and the tourist industry. Tourism not only introduces ethnicity into the field of trade relations but also re-evaluates ethnic culture and history. From the signs of backwardness, ethnic culture, heritage becomes a moral value, social and economic resource, and reason to be proud. Thus the Huns, as an element of the new public history, have become a part of national ideologies and municipal marketing alike. The past is represented not only by academics, museum workers, and officials. New spokespersons (shamans, reconstructors, rockers) have appeared in the urban space, re-assembling urban space, its inhabitants and archaeological excavations, sacred places and narratives about the past.

\section{Bibliography}

Amar A.

[1934] 2014 Mongolyn tovch tü̈̈kh, Ulaanbaatar. Anderson B.

1991 Imagined Communities: Reflections on the Origin and Spread of Nationalism, London.

Atwood Ch.

2012 Huns and Xiōngnú: New Thoughts on an Old Problem in: B. Boeck, R. Martin, D. Rowland (eds.), Dubitando: Studies in History and Culture in Honor of Donald Ostrowski, Bloomington, pp. 27-52.

Baabar B.

1999 History of Mongolia: From World Power to Soviet Satellite, trans. D. Sukhjargalma et al., Cambridge.

Badmaeva L.

2005 Yazyk buryatskikh letopisei, Ulan-Ude.

Bakhtin M.

1981 Forms of Time and the Chronotope in the Novel: Notes towards a Historical Poetics in: M. Holquist (ed.), The Dialogic Imagination: Four Essays, Austin, pp. 84-258. 
Basso K.

1996 Wisdom Sits in Places: Landscape and Language Among the Western Apache, Albuquerque.

Billig M.

1995 Banal Nationalism, London.

Bira Š.

2000 Early Mongolian Political Concepts (1 $3^{\text {th }}-14^{\text {th }}$ Centuries), "Journal of the Korean Association for Mongolian Studies", nr 9, s. 53-68.

2004 Mongolian Tenggerism and Modern Globalism. A Retrospective Outlook on Globalisation, „Journal of the Royal Asiatic Society”, nr 14 (1), s. 3-12.

Breslavsky A.

2012 Post-Soviet Ulan-Ude: Content and Meaning of a New Urban Idea, "Inner Asia", vol. 14 (2), pp. 299-317.

Brubaker R.

2004 Ethnicity Without Groups, Cambridge.

Bulag U.

1998 Nationalism and Hybridity in Mongolia, New York.

2002 From Yeke-juu League to Ordos Municipality: Settler Colonialism and Alter/native Urbanization in Inner Mongolia, "Provincial China", vol. 7 (2), pp. 196-234.

Bulutov O.

2012 Ulan-Ude - eto Udyn Adag, "Buriatiia”, June 13.

Coakley J.

2004 Mobilizing the Past: Nationalist Images of History, "Nations and Nationalism", vol. 10 (4), pp. 531-560.

Comaroff J., Comaroff J.

2009 Ethnicity, Inc., Chicago.

Dašibalova I.

2017 Gorodskie ritualy kak mechanizm konstruirovaniâ simvoličeskogo prostranstva goroda: postsovetskij tranzit Ulan-Udè in: A. Bazarov, A. Yavlovskiy (eds.), Ulan-Ude Varshava. Dva goroda, dva mira, obshchiie problemy i nauchno-issledowatielskiie vyzovy, Varshava, pp. 309-342.

Diener A., Hagen J.

2013 City of Felt and Concrete: Negotiating Cultural Hybridity in Mongolia's Capital of Ulaanbaatar, "Nationalities Papers: The Journal of Nationalism and Ethnicity", vol. 41 (4), pp. 622-650.

Dohnal A.

2015 The Basis of Modern Mongolian Statehood in the Thought of Shagdaryn Bira, "Eurasia: statum et legem", vol. 1 (4), pp. 198-207.

Dovey K.

2015 Becoming Places: Urbanism/Architecture/Identity/Power, New York. Enteen G.

1978 The Soviet Scholar-bureaucrat: M.N. Pokrovskil and the Society of Marxist Historians, London.

Gill G.

2013 Symbolism and Regime Change in Russia, Cambridge- New York.

Goffman E.

1986 Frame Analysis: An Essay on the Organization of Experience, Boston. 
Gordon A.

2001 Making Public Pasts. The Contested Terrain of Montreal's Public Memories, 18911930, Montréal.

Gökay B., Aybak T.

2016 Identity, Race and Nationalism in Turkey - Introduction to the Special Issue, "Journal of Balkan and Near Eastern Studies", vol. 18 (2), pp. 107-110.

Guggenheim M.

2009 Building Memory: Architecture, Networks and Users, "Memory Studies", vol. 2 (1), pp. 39-53.

Gumilev L.

1960 Khunnu: Sredinnaia Aziia v drevnie vremena, Moscow.

Herzfeld M.

2006 Spatial Cleansing. Monumental Vacuity and the Idea of the West, "Journal of Material Culture", vol. 11 (1/2), pp. 127-149.

Humphrey C.

1992 The Moral Authority of the Past in Post-Socialist Mongolia, "Religion, State and Society", vol. 20 (3-4), pp. 375-389.

Hürelbaatar A.

2007 The Creation and Revitalisation of Ethnic, Sacred Sites in Ulan-Ude since 1990s in: C. Alexander, V. Buchli, C. Humphrey (eds.), Urban Life in Post-Soviet Asia, London-New York, pp. 136-156.

Kaplonski Ch.

1999 Blame, Guilt and Avoidance: The Struggle to Control the Past in Post-Socialist Mongolia, "History \& Memory", vol. 11 (2), pp. 94-114.

2004 Truth, History and Politics in Mongolia: Memory of Heroes, London.

2005 The Case of the Disappearing Chinggis Khaan: Dismembering the Remembering, "Ab Imperio", vol. 4, pp. 147-173.

Kürti L.

2015 Neoshamanism, National Identity and the Holy Crown of Hungary, "Journal of Religion in Europe”, vol. 8 (2), pp. 235-260.

2016 Nomadism and nostalgia in Hungary in: M. Palmberger, J. Tošić (eds.), Memories on the Move. Experiencing Mobility, Rethinking the Past, London, pp. 217-246.

Mashbat S.

2004 Mongolia: Managing the Transition from Nomadic to Settled Culture in: J. Rolfe (ed.), The Asia-Pacific: A Region in Transition, Honolulu, pp. 323-334.

350 Years of Voluntary Entry of Buryatia into the Russian State

Nandy A.

1995 History's Forgotten Doubles, “History \& Theory”, vol. 34 (2), pp. 44-66.

Nowicka E.

2015 Towards the Creation of Modern Ethnicity and Imagined Community: Ethnofestivals and Constructing the Buryat Nation, "Etnografia Polska", vol. 59 (1-2), pp. 141-154.

Nowicka E., Wyszyński R.

1996 Lamowie i sekretarze. Poziomy więzi społecznej we współczesnej Buriacji, Warszawa.

Pedersen M.

2006 Tarrying with Repression: Political Anecdotes and Social Memory in Northern Mongolia, "Inner Asia”, vol. 8 (2), pp. 163-181. 
Quijada J.

2019 Buddhists, Shamans, and Soviets: Rituals of History in post-Soviet Buryatia, New York.

Sahlins M.

1983 Other Times, Other Customs: The Anthropology of History, "American Anthropologist", vol. 85 (3), pp. 517-544.

Schiller N. Wimmer A.

2002 Methodological Nationalism and Beyond: Nation-state Building, Migration and the Social Sciences, “Global Networks”, vol. 2 (4), pp. 301-334.

Stewart Ch.

2016 Historicity and Anthropology, "Annual Review of Anthropology", vol. 45, pp. 79-94.

Shnirelman V., Panarin S.

2001 Lev Gumilev: His Pretensions as Founder of Ethnology and his Eurasian Theories, "Inner Asia", vol. 3 (1), pp. 1-18.

Tangad O.

2016 Cultural Aspects of Democratization in Mongolia: The Ethical Perspective, "Ethnologia Polona”, vol. 37, pp. 133-144.

Vasilev B.

2015 Ust'e Udy - sviatoe mesto, gde dolzhny stoiat' tol'ko dva sviashchennykh Oboo i nichego bol'she, May 26, http://babr24.com/bur/?IDE=136059 (access: 15.08.2019).

White $\mathrm{H}$.

2012 Politics, History, and the Practical Past, "Storia della Storiografia", vol. 61 (1), pp. 127-134.

Whitehead N.

2003 Histories and Historicities in Amazonia, Lincoln-London. 